\title{
PDE4B wt Allele
}

National Cancer Institute

\section{Source}

National Cancer Institute. PDE4B wt Allele. NCI Thesaurus. Code C95573.

Human PDE4B wild-type allele is located in the vicinity of 1 p31 and is approximately 582 $\mathrm{kb}$ in length. This allele, which encodes cAMP-specific 3',5'-cyclic phosphodiesterase 4B protein, is involved in the regulation of second messenger signaling. 